\title{
Expression of the Surface Properties of the Fibrillar Streptococcus salivarius HB and Its Adhesion Deficient Mutants Grown in Continuous Culture under Glucose Limitation
}

\author{
By DEREK W. S. HARTY† AND PAULINE S. HANDLEY* \\ Department of Cell and Structural Biology, Stopford Building, Manchester University, \\ Oxford Road, Manchester M13 9PT, UK
}

(Received 22 February 1989; revised 26 May 1989; accepted 23 June 1989)

\begin{abstract}
Streptococcus salivarius HB and four adhesion deficient mutants, HB-7, HB-V5, HB-V51 and HB-B, were grown in continuous culture in a defined medium under glucose limitation over a range of growth rates from $0 \cdot 1$ to $1 \cdot 1 \mathrm{~h}^{-1}$. The ability to coaggregate with Veillonella parvula $\mathrm{V} 1$ cells and the ability to adhere to buccal epithelial cells did not alter with increasing growth rate. Cell surface hydrophobicity decreased markedly with increasing growth rate for the nonfibrillar non-adhesive mutant HB-B but not for the other four strains which all carry different combinations of fibril classes. The thickness of the ruthenium red staining layer (RRL) also varied with growth rate for strain HB-B, ranging from $19.5 \pm 3.8 \mathrm{~nm}$ at high growth rate to a minimum of $12.3 \pm 4.8 \mathrm{~nm}$ at low growth rate. Low cell surface hydrophobicity correlated with a thicker RRL for strain HB-B. Strains HB-V5 and HB-7 also showed a significant increase in RRL thickness at high growth rates although to a lesser degree than HB-B. SDS-PAGE revealed a large number of protein bands common to all strains at all growth rates, with the major common protein occurring at $15.6 \mathrm{kDa}$. Protein bands at $70,56,40.5$ and $39 \mathrm{kDa}$ appeared stronger at high growth rates than at low. A protein band at $82 \mathrm{kDa}$ showed strongly only at low growth rates. Therefore, adhesion and coaggregation are not phenotypically variable with increasing growth rate but RRL thickness, hydrophobicity and cell surface proteins may be phenotypically variable depending on the strain.
\end{abstract}

\section{INTRODUCTION}

The Streptococcus salivarius HB cell surface carries a complex fibrillar mosaic consisting of four different classes of fibrils and each fibril class is identified by a specific length (Handley et al., 1984; Weerkamp et al., 1986). The functions of two of the fibril classes have been identified: $91 \mathrm{~nm}$ fibrils [antigen $\mathrm{B}$ (AgB) or Veillonella-binding protein (VBP)] are responsible for coaggregation with Veillonella parvula $\mathrm{V} 1$ cells; $73 \mathrm{~nm}$ fibrils [antigen $\mathrm{C}(\mathrm{AgC})$ ] are responsible for host associated adhesion properties, including buccal epithelial cell (BEC) adhesion (Weerkamp et al., 1986; Weerkamp \& Jacobs, 1982). The longest fibrils (178 nm) and the shortest fibrils $(63 \mathrm{~nm})$ have no known function. Underneath the fibrils is a dense ruthenium red staining layer (RRL; $16.2 \mathrm{~nm}$ thick for strain $\mathrm{HB}$ ) outside the cell wall which contains polyanionic polymers. The composition and function of this layer is unknown (Handley et al., 1988).

Weerkamp et al. (1984) suggested that there was variation in the expression of the functions of $\mathrm{AgB}$ and $\mathrm{AgC}$ with changing growth rate under glucose limitation in a chemostat, and

† Present address: Institute of Dental Research, United Dental Hospitals of Sydney, Chalmers Street, Surry Hills, Sydney, New South Wales, Australia.

Abbreviations: AgB, AgC, antigens B and C; BEC, buccal epithelial cell(s); LTA, lipoteichoic acid; RRL, ruthenium red staining layer; SLS, sodium lauroyl sarcosinate; VBP, Veillonella-binding protein. 
Weerkamp \& Handley (1986) showed that the amount of fibrillar AgB and $\mathrm{AgC}$ on the surface of $S$. salivarius $\mathrm{HB}$ varied with increasing growth rate. These studies indicated a phenotypic variability in the fibrillar $\mathrm{AgB}$ and $\mathrm{AgC}$. There can also be phenotypic variations in nonstructural components of the cell surface of other Gram-positive oral streptococci, such as strains of $S$. sanguis and $S$. mutans. The highest activity of $S$. mutans extracellular glucosyltransferase was reported at low growth rates (Ellwood \& Hunter, 1976; Carlsson \& Elander, 1973). Jacques et al. (1979) reported that the cellular lipoteichoic acid (LTA) of $S$. mutans Ingbritt was highest at the higher growth rate while extracellular LTA was highest at low growth rate. Rosan et al. (1982) have shown that the expression of surface proteins and adhesive properties in $S$. sanguis G9B, under defined conditions in a chemostat, could vary severalfold depending on the generation time and the $\mathrm{pH}$. Campbell et al. (1983) demonstrated that adhesion to saliva coated hydroxylapatite increased as the $\mathrm{pH}$ was increased from 5.5 to 7.5 and also varied with increasing growth rate under different limiting substrates. Evidence for variation in extracellular protein profiles of strains of $S$. mutans serotype $c$ has been demonstrated when grown on glucose or fructose at $\mathrm{pH} 6.0$ (Knox et al., 1986). Variation in cell surface hydrophobicity has also been reported with strains of $S$. mutans and $S$. milleri (Rogers $e t$ al., 1984), with hydrophobicity decreasing with increasing growth rate. These studies show that phenotypic variability of cell surface properties in oral streptococci is extremely common and is growth rate dependent.

Some properties, however, are stable as growth rate changes. A considerable degree of stability in cell wall components has been shown by the analysis of teichoic acids, polysaccharides and peptidoglycans of $S$. mutans Ingbritt when grown under carbohydrate limitation (Knox et al., 1979). Also, in a recent study Harty \& Handley (1989) compared the adhesion, coaggregation and hydrophobicity of $S$. salivarius $\mathrm{HB}$ at a range of growth rates when grown under glucose limitation and found no statistical differences when increasing the growth rate from $0 \cdot 1$ to $1 \cdot 1 \mathrm{~h}^{-1}$, indicating a lack of variability in the expression of these adhesion processes. This paper investigates in greater detail the effect of varying growth rate on BEC adhesion, coaggregation with $V$. parvula $\mathrm{V} 1$, cell surface ultrastructure, cell surface hydrophobicity and surface protein profiles in order to investigate the presence or absence of phenotypic variability of these properties on the surface of $S$. salivarius HB. A series of adhesion deficient mutants (Handley et al., 1987) are included for comparison because of their known fibrillar and adhesive properties (Weerkamp et al., 1987).

\section{METHODS}

Organisms. Streptococcus salivarius HB, HB-7, HB-V5 and HB-V51 and Veillonella parvula strain V1 were kindly provided by Dr A. H. Weerkamp, University of Groningen, The Netherlands. S. salivarius HB and its mutants have been described previously (Weerkamp et al., 1986; Weerkamp \& McBride 1980, 1981). Briefly, mutant HB-7 has lost the host associated adhesin (AgC), mutant HB-V5 has lost the VBP (AgB) and HB-V51 has lost both. S. salivarius HB-B, a stable mutant, was isolated as being non-fibrillar, non-coaggregating and non-adhering from a chemostat culture of strain HB at low dilution rate $\left(<0 \cdot 1 \mathrm{~h}^{-1}\right)$ (Harty \& Handley, 1988; Handley et al., 1988). The identity of the mutant HB-B was confirmed by the API 20 Strep test as being $S$. salivarius.

Media. In all experiments a filter sterilized, chemically defined medium was used (Harty \& Handley, 1988). This medium was adapted from the media of Christie \& Porteous (1962) and Terleckyj et al. (1975) by Dr A. H. Weerkamp (personal communication) and contained, in $\mathrm{mg} \mathrm{1^{-1 }}$ : glucose, $3600 ; \mathrm{Na}_{2} \mathrm{CO}_{3} \cdot 10 \mathrm{H}_{2} \mathrm{O}, 5400$; $\mathrm{K}_{2} \mathrm{HPO}_{4} .3 \mathrm{H}_{2} \mathrm{O}, 760 ; \mathrm{NaH}_{2} \mathrm{PO}_{4} .2 \mathrm{H}_{2} \mathrm{O}, 500 ; \mathrm{Na}_{3} \mathrm{C}_{6} \mathrm{H}_{5} \mathrm{O}_{7} .2 \mathrm{H}_{2} \mathrm{O}, 250 ;\left(\mathrm{NH}_{4}\right)_{2} \mathrm{SO}_{4}, 600 ; \mathrm{NaCl}, 10 ;$ $\mathrm{CaCl}_{2} .2 \mathrm{H}_{2} \mathrm{O}, 20 ; \mathrm{MnSO}_{4} \cdot 4 \mathrm{H}_{2} \mathrm{O}, 11 ; \mathrm{MgSO}_{4} .7 \mathrm{H}_{2} \mathrm{O}, 700 ; \mathrm{FeSO}_{4} .7 \mathrm{H}_{2} \mathrm{O}, 18 ; \mathrm{Na}_{2} \mathrm{MoO}_{4} .2 \mathrm{H}_{2} \mathrm{O}, 0.15$; adenine, 35; guanine, 27; uracil, 30; L-cysteine hydrochloride, 300; L-glutamic acid, 300; L-tyrosine, L-tryptophan, L-phenylalanine, L-proline, DL-alanine, L-arginine, glycine, L-histidine, all 200; L-aspartic acid, L-asparagine, L-isoleucine, L-leucine, L-lysine, L-serine, L-threonine, L-valine, L-methionine, all 100; L-glutamine, 50; pantothenic acid, calcium salt, 4-aminobenzoic acid, nicotinic acid, folic acid, riboflavin, thiamin hydrochloride, $m$-inositol, all 2.0 ; pyridoxal 5 -phosphate, 0.5 ; pyridoxine hydrochloride, $0.5 ; p$-biotin, 0.1 ; the $\mathrm{pH}$ was brought to $\mathrm{pH} 7.0$ with $3 \mathrm{M}-\mathrm{KOH}$. All chemicals were of analytical grade from either BDH or Sigma.

$V$. parvula strain V1 was grown on the medium described by Cisar $e$ t al. (1979) containing $\mathrm{g}^{-1}:$ tryptone, 5 ; yeast extract, $5 ; \mathrm{Na}_{2} \mathrm{HPO}_{4}, 5 ; 0.05 \%(\mathrm{v} / \mathrm{v})$ Tween 80 and $10 \mathrm{ml} 1^{-1} 70 \%(\mathrm{w} / \mathrm{w})$ sodium lactate. The final $\mathrm{pH}$ of the medium was 7.4. Static batch cultures were grown at $37^{\circ} \mathrm{C}$ for $24-48 \mathrm{~h}$ in an anaerobic cabinet. Harvested cells 
were washed three times in phosphate-buffered saline (PBS; $8.0 \mathrm{~g} \mathrm{NaCl} \mathrm{l}^{-1} ; 1.21 \mathrm{~g} \mathrm{~K}_{2} \mathrm{HPO}_{4} .3 \mathrm{H}_{2} \mathrm{O} \mathrm{^{-1 }}, 0.34 \mathrm{~g}^{-1}$ $\mathrm{KH}_{2} \mathrm{PO}_{4} \mathrm{1}^{-1}, \mathrm{pH} 7 \cdot 2$ ) and kept at $4{ }^{\circ} \mathrm{C}$ until required. Stock cultures of the Veillonella strain were maintained in an anaerobic cabinet on agar slopes of the above medium or were freeze dried for long term storage. Stock cultures of the streptococci were maintained in Brain Heart Infusion (BHI) broth plus $0.3 \%$ yeast extract and were preserved with $50 \%(\mathrm{v} / \mathrm{v})$ glycerol at $-70^{\circ} \mathrm{C}$. For short-term use cultures were plated on BHI agar with $5 \%(\mathrm{v} / \mathrm{v})$ horse blood.

Chemostat growth conditions. The organisms were grown in a series 500 fermenter (LH Fermentation) with a working volume of $400 \mathrm{ml}$; the temperature was maintained at $37^{\circ} \mathrm{C} \pm 1.0$; the $\mathrm{pH}$ was controlled, by the automatic addition of $3 \mathrm{M}-\mathrm{NaOH}$, at 7.0 $\pm 0 \cdot 1$; the culture was agitated by a magnetically driven impeller at 750 r.p.m. and surface gassed with $5 \%(v / v) \mathrm{CO}_{2}$ in nitrogen at a flow rate of $75 \mathrm{ml} \mathrm{min}^{-1}$. Medium flow was controlled by a peristaltic pump (Pharmacia). The inoculum $(10 \%, \mathrm{v} / \mathrm{v})$ for the chemostat was a static batch culture grown in a candle jar under reduced oxygen tension for $18 \mathrm{~h}$ at $37^{\circ} \mathrm{C}$. Cultures were assumed to be in a steady state when at least six volumes had passed through the chemostat. Culture purity was checked periodically by microscopic examination and by plating on $\mathrm{BHI} / 5 \%$ horse blood agar plates incubated at $37{ }^{\circ} \mathrm{C}$ in a candle jar.

Coaggregation assay. The coaggregation assay was done spectrophotometrically as described in Handley et al. (1987), except the buffer used was PBS at $\mathrm{pH} 7 \cdot 3$. Briefly, a suspension $\left(0.5 \mathrm{ml}, \mathrm{OD}_{660} 1 \cdot 0\right)$ of the S. salivarius strain from a chemostat steady state was mixed with an equal volume of a Veillonella strain at the same optical density (in triplicate) in a $1.6 \mathrm{ml}$ semimicro plastic cuvette (Plastibrand), mixed by inversion and the optical density measured at times over a $24 \mathrm{~h}$ period. Control tubes contained $1 \mathrm{ml}$ of either bacterial suspension. The percentage coaggregation was calculated using the following equation

$$
\frac{\left(S_{\mathrm{CT}}+V_{\mathrm{CT}}\right) / 2-(S+V)_{\mathrm{T}}}{\left(S_{\mathrm{CT}}+V_{\mathrm{CT}}\right) / 2} \times 100
$$

where

$S_{\mathrm{CT}} \quad=$ streptococcal control at time $T$.

$V_{\mathrm{CT}} \quad=$ Veillonella control at time $T$.

$(S+V)_{\mathrm{T}}=$ streptococcal and Veillonella mixture at time $T$.

$B E C$ adhesion. The method used was an adaptation of that described in Handley et al. (1987) not involving the use of a radiolabel. BEC were collected from one source (D. W.S.H) into PBS and washed three times, and then resuspended to an $\mathrm{OD}_{550}$ of $0.2\left(1-2 \times 10^{6} \mathrm{BEC} \mathrm{ml}^{-1}\right.$ by direct count). For the assay $0.5 \mathrm{ml}$ each of the standardized BEC suspension and the washed sample from the chemostat at an $\mathrm{OD}_{550}$ of $0.6\left(10^{8}\right.$ bacterial cells $\mathrm{ml}^{-1}$ by direct count), were incubated in a Bijou bottle at room temperature on a rotary device $(20$ r.p.m.) for 30 min. Control bottles containing $0.5 \mathrm{ml} \mathrm{BEC}$ suspension and $0.5 \mathrm{ml}$ PBS were set up for a background count of adhered bacteria. Samples $(0.5 \mathrm{ml})$ of the assay mixture were layered onto $5 \mathrm{ml} \mathrm{6 \%}(\mathrm{w} / \mathrm{v})$ dextran (Dextraven 110 , Fisons) in glass test-tubes and centrifuged at $500 \mathrm{~g}$ for $5 \mathrm{~min}$ to sediment the BEC leaving the unattached bacteria about $1 \mathrm{~cm}$ down the column. After removal of the top $4.5 \mathrm{ml}$ of dextran the remaining dextran containing the BEC was washed once in PBS to remove the dextran. Samples were then placed on microscope slides, dried and lightly heat-fixed by passing the slide through a flame. A dilute solution of crystal violet was used to stain the adhered bacteria. A microscopic count of 30 BEC was made.

Hexadecane partition assay. The method used was an adaptation of the method of Rosenberg et al. (1980) as described in Handley et al. (1987). Cells from a chemostat steady state were washed three times in Sorenson's phosphate buffer $(0.66 \mathrm{M} ; \mathrm{pH} 7.2)$ and resuspended to an $\mathrm{OD}_{440}$ of 0.5 . Samples of this suspension (3.0 ml) were blended on a vortex mixer for $60 \mathrm{~s}$ after $200 \mu \mathrm{l}$ hexadecane had been layered on the top. The tubes were left to stand for $15 \mathrm{~min}$ for the phases to separate and the $\mathrm{OD}_{440}$ of the aqueous phase was measured. The percentage hydrophobicity was calculated from six replicates as the percentage reduction in the original optical density of the bacterial suspension due to partitioning of the cells into the hexadecane layer (Handley et al., 1987).

Ruthenium red staining. A modification of the method employed by Luft (1971) was used. A stock solution of ruthenium red (Johnson \& Matthey Chemicals) was made up in water to give a final concentration of $10 \mathrm{mg} \mathrm{ml}^{-1}$ (1500 p.p.m.). Cells were washed three times in $0.2 \mathrm{M}$-sodium cacodylate buffer, $\mathrm{pH} 7 \cdot 3$, and fixed initially with $0.5 \mathrm{ml} 3.6 \%(\mathrm{v} / \mathrm{v})$ glutaraldehyde, $0.5 \mathrm{ml} 0.2 \mathrm{M}$ cacodylate buffer and $0.5 \mathrm{ml}$ of the ruthenium red stock solution overnight. After three washings in $0.2 \mathrm{M}$-cacodylate buffer, cells were fixed in a mixture of $0.5 \mathrm{ml} 4 \%(\mathrm{w} / \mathrm{v}) \mathrm{osmium}$ tetroxide in distilled water, $0.5 \mathrm{ml} 0.2 \mathrm{M}$-cacodylate buffer and $0.5 \mathrm{ml}$ of the ruthenium red stock solution overnight. Controls were prepared by substituting distilled water for the ruthenium red solution. Cells were then washed three times in cacodylate buffer, dehydrated in a graded series of ethanol and embedded in LR white resin (London Resin Co.). Sections were cut on a Reichart OMU4 microtome and were photographed on a Hitachi H600 electron microscope; 30 measurements of the RRL thickness were made from separate micrographs for statistical analysis.

Extraction of surface proteins. The method was an adaptation of that described by Jenkinson (1986). Cells from chemostat culture, equivalent to $60 \mathrm{mg}$ dry wt, were washed in $0.15 \mathrm{M}-\mathrm{NaCl}$, centrifuged at $6000 \mathrm{~g}$ and resuspended in $0.2 \mathrm{ml} 1 \%(\mathrm{w} / \mathrm{v})$ sodium lauroyl sarcosinate (SLS) in $10 \mathrm{mM}$-Tris/ $\mathrm{HCl}(\mathrm{pH} 7.5)$ containing $1 \mathrm{mM}$ - 
$\mathrm{Na}_{2}$ EDTA and $0.005 \%(\mathrm{w} / \mathrm{v})$ dithiothreitol. The cells were vortex mixed and rotated at 20 r.p.m. for $20 \mathrm{~min}$ at room temperature. The suspension was then centrifuged and the supernatant removed and further centrifuged. Protein concentration of the extract was determined by a modified Lowry assay. The cell pellet was washed in $0 \cdot 15 \mathrm{M}-\mathrm{NaCl}$ and stored at $4{ }^{\circ} \mathrm{C}$.

Protease treatment of cell surface proteins. Cells were washed as for cell surface proteins extraction (Jenkinson, 1986) and resuspended in $10 \mathrm{mM}-\mathrm{Tris} / \mathrm{HCl}, \mathrm{pH} 7.5(1 \mathrm{ml})$. A stock solution of protease $10 \mathrm{mg} \mathrm{ml}^{-1}$ (protease type XIV from Streptomyces griseus; Sigma) in $10 \mathrm{~mm}-\mathrm{Tris} / \mathrm{HCl}, 0.15 \mathrm{M}-\mathrm{NaCl}, \mathrm{pH} 7 \cdot 5$, self-digested for $2 \mathrm{~h}$ at $37^{\circ} \mathrm{C}$, was added to the required concentration and incubated at $20^{\circ} \mathrm{C}$ for $20 \mathrm{~min}$.

$S D S-P A G E$. Samples of the SLS extract containing $75 \mu \mathrm{g}$ protein were diluted with $20 \mu \mathrm{l} 70 \%(\mathrm{v} / \mathrm{v})$ glycerol containing $0.05 \%(\mathrm{w} / \mathrm{v})$ bromophenol blue and electrophoresed through $13 \%(\mathrm{w} / \mathrm{v})$ acrylamide gels containing $0.1 \%$ SDS by the system of Laemmli \& Favre (1973). Gels were stained with Coomassie Blue, destained and photographed. Molecular masses of proteins were estimated from their distances of migration by reference to a plot of the relative mobility of seven marker proteins against log molecular mass. The markers were bovine serum albumin (BSA) (66 kDa), chicken egg albumin (45 kDa), glyceraldehyde-3-phosphate dehydrogenase (36 kDa), bovine carbonic anhydrase $(29 \mathrm{kDa})$, bovine pancreas trypsinogen $(24 \mathrm{kDa})$, soybean trypsin inhibitor $(20 \cdot 1 \mathrm{kDa})$ and bovine milk $\alpha$-lactalbumin ( $14 \cdot 2 \mathrm{kDa})$ (Sigma).

Statistical analysis. To test for differences in adherence to BEC and the thickness of the ruthenium red staining layer between strains and between growth rates for each strain, the variance ratio of variability between strains to variability between growth rates for each strain was calculated.

\section{RESULTS}

\section{Adhesion to BEC, cell surface hydrophobicity and coaggregation with $V$. parvula VI}

Table 1 shows the mean number of bacteria attached to BEC and the percentage cell surface hydrophobicity for $S$. salivarius HB and HB-B for growth rates between $0 \cdot 1$ and $1 \cdot 138 \mathrm{~h}^{-1}$. Table 2 shows representative values (three from at least seven growth rates) for the other three mutants, HB-7, HB-V5 and HB-V51. The control values represent the mean number of attached indigenous bacteria in the normal flora on the BEC. No significant difference was found between the control values $(P=0 \cdot 186)$. Statistical analysis of the adhesion of the strains at the different growth rates showed that there was no significant difference between adhesion to BEC at different growth rates for strain HB $(P=0.272)$ and HB-7 $(P=0.846)$, but the mean adhesion values for HB-B and HB-V5 were significantly different, being $P=0.035$ for HB-B and $P=$ 0.0162 for HB-V5. However, only one of the growth-rate values for HB-B was significantly different from the rest. For HB-B the lowest growth rate $\left(0.106 \mathrm{~h}^{-1}\right)(P=0.058)$ and for HB-V5 adhesion at a growth rate of $0.2 \mathrm{~h}^{-1}(P=0.034)$ were significantly different from values at the other growth rates covered. Strain HB-V51, a mutant of strain HB-V5, showed little adhesion, not possessing the host adhesion fibrils. However, a significant difference was observed within the growth rates covered $\left(P=7.5 \times 10^{-4}\right)$. These significant differences are probably due to inherent inaccuracies in the adhesion assay. For example, it is difficult to count large numbers of adhering bacteria accurately and there may be variations in the surface properties of the BEC, depending on whether they come from the surface or the underlying layers of the epithelium.

Tables 1 and 2 also show the percentage cell surface hydrophobicity as measured by partitioning with hexadecane. Cell surface hydrophobicity was consistently high for the wildtype strain HB and the mutant strain HB-7. However, the mutant HB-B showed a reduction in hydrophobicity with increasing growth rate, the percentage hydrophobicity falling from $66.5 \pm$ $6.2 \%$ at a growth rate of $0.106 \mathrm{~h}^{-1}$ to $12.2 \pm 2.7 \%$ at the highest growth rate $\left(1.138 \mathrm{~h}^{-1}\right)$ (Table 1).

Strains HB-V5 and HB-V51 showed a lower percentage hydrophobicity than HB or HB-7 but little variation with changing growth rate. All hydrophobicity values were reduced compared to those found when the strains were grown in static batch culture in the defined medium for $7 \mathrm{~h}$ under reduced oxygen tension in a candle jar.

For the two strains that coaggregated with $V$. parvula $\mathrm{V} 1$, HB coaggregated to $95.0 \pm 2.0 \%$ after $24 \mathrm{~h}(53.8 \pm 11.8 \%$ at $1 \mathrm{~h})$ and HB-7 coaggregated to a level of $91.6 \pm 3.7 \%$ after $24 \mathrm{~h}(37.1$ $\pm 17.9 \%$ at $1 \mathrm{~h}$ ). These values are the mean of 15 coaggregation values taken from the triplicate tests at five different growth rates between 0.1 and $1 \cdot 1 \mathrm{~h}^{-1}$ (including the lowest and the highest growth rates studied). The results therefore show there was no fluctuation in the coaggregative 
Table 1. Adhesion to BEC and hydrophobicity of S. salivarius strains $H B$ and $H B-B$

\begin{tabular}{|c|c|c|c|}
\hline Strain & $\begin{array}{c}\text { Dilution rate } \\
\left(\mathrm{h}^{-1}\right)\end{array}$ & $\begin{array}{l}\text { Adhesion } \\
\text { (streptococci per } \\
\text { one BEC)* }\end{array}$ & $\begin{array}{c}\text { Hydrophobicity } \\
(\%)\end{array}$ \\
\hline HB & $\begin{array}{c}\text { Control‡ } \\
\text { Batch } \S \\
0.104 \\
0.221 \\
0.356 \\
0.449 \\
0.717 \\
1.06\end{array}$ & $\begin{array}{c}11 \pm 9 \\
- \\
247 \pm 176 \\
228 \pm 494 \\
125 \pm 235 \\
135 \pm 88 \\
209 \pm 118 \\
160 \pm 125\end{array}$ & $\begin{array}{c}- \\
98.2 \pm 0.5 \\
87.1 \pm 4.3 \\
93.6 \pm 2.7 \\
93.4 \pm 4.7 \\
87.8 \pm 5.7 \\
95.4 \pm 4.0 \\
94.2 \pm 4.0\end{array}$ \\
\hline HB-B & $\begin{array}{c}\text { Control } \ddagger \\
\text { Batch } \S \\
0.106 \\
0.139 \\
0.169 \\
0.278 \\
0.508 \\
0.698 \\
1.138\end{array}$ & $\begin{array}{c}16 \pm 20 \\
- \\
42 \pm 50 \\
\mathrm{ND} \\
20 \pm 23 \\
13 \pm 13 \\
19 \pm 39 \\
\mathrm{ND} \\
25 \pm 43\end{array}$ & $\begin{array}{c}- \\
74.6 \pm 7.2 \\
66.5 \pm 6.2 \\
67.0 \pm 5.7 \\
54.8 \pm 4.3 \\
21.8 \pm 3.2 \\
16.8 \pm 2.3 \\
13.5 \pm 2.7 \\
12.2 \pm 2.7\end{array}$ \\
\hline
\end{tabular}

ND, Not done.

* Streptococci attached to $30 \mathrm{BEC}$ were counted.

$\uparrow$ Cell surface hydrophobicity values were determined for a $7 \mathrm{~h}$ static batch culture grown in defined medium under reduced oxygen tension.

$\ddagger$ Control values represent the mean number of indigenous bacteria attached to each BEC.

$\S$ Six separate samples partitioned between hexadecane and buffer to produce a mean \pm SD.

Table 2. Adhesion to BEC and hydrophobicity of $S$. salivarius strains $H B-7, H B-V 5$ and $H B-V 51$

\begin{tabular}{|c|c|c|c|}
\hline Strain & $\begin{array}{l}\text { Dilution rate } \\
\qquad\left(\mathrm{h}^{-1}\right)\end{array}$ & $\begin{array}{c}\text { Adhesion } \\
\text { (streptococci per } \\
\text { one BEC)* }\end{array}$ & $\begin{array}{c}\text { Hydrophobicity } † \\
(\%)\end{array}$ \\
\hline HB-7 & $\begin{array}{c}\text { Control } \ddagger \\
\text { Batch } \S \\
0 \cdot 115 \\
0.408 \\
1 \cdot 13\end{array}$ & $\begin{array}{c}3.9 \pm 7.8 \\
\quad- \\
2.7 \pm 3.4 \\
5.3 \pm 11.4 \\
6.8 \pm 27.2\end{array}$ & $\begin{array}{c}- \\
98.6 \pm 0.5 \\
94.0 \pm 1.4 \\
92.0 \pm 3.2 \\
96.3 \pm 1.0\end{array}$ \\
\hline HB-V5 & $\begin{array}{c}\text { Control } \\
\text { Batch } \S \\
0.098 \\
0.50 \\
1.02\end{array}$ & $\begin{array}{c}15.6 \pm 41.2 \\
- \\
143.2 \pm 92.2 \\
173.6 \pm 195 \\
190.6 \pm 149\end{array}$ & $\begin{array}{c}- \\
98.4 \pm 0.6 \\
81.6 \pm 3.5 \\
87.2 \pm 7.4 \\
89.7 \pm 4.1\end{array}$ \\
\hline HB-V51 & $\begin{array}{c}\text { Control } \ddagger \\
\text { Batch } \\
0.135 \\
0.578 \\
1.00\end{array}$ & $\begin{array}{c}5.2 \pm 8.2 \\
\pm \\
7.4 \pm 5.3 \\
4.5 \pm 5.8 \\
3.1 \pm 3.5\end{array}$ & $\begin{array}{l}97.6 \pm 1.8 \\
81.7 \pm 2.9 \\
63.1 \pm 2.2 \\
83.9 \pm 11.5\end{array}$ \\
\hline
\end{tabular}

$*, \dagger, \ddagger$, as Table 1 .

ability with increasing growth rate for these two strains. Strains HB-B, HB-V5 and HB-V51 all gave less than $5 \%$ coaggregation with $V$. parvula $\mathrm{V} 1$ at all growth rates tested as they lack AgB (VBP).

\section{$R R L$ thicknesses}

Samples of all $S$. salivarius strains from the chemostat at low and high growth rates were stained with ruthenium red and thin sectioned. Micrographs of the sections were examined for the presence of a RRL. Fig. 1 (a) shows a ruthenium red stained cell of HB-V5 grown at a growth 

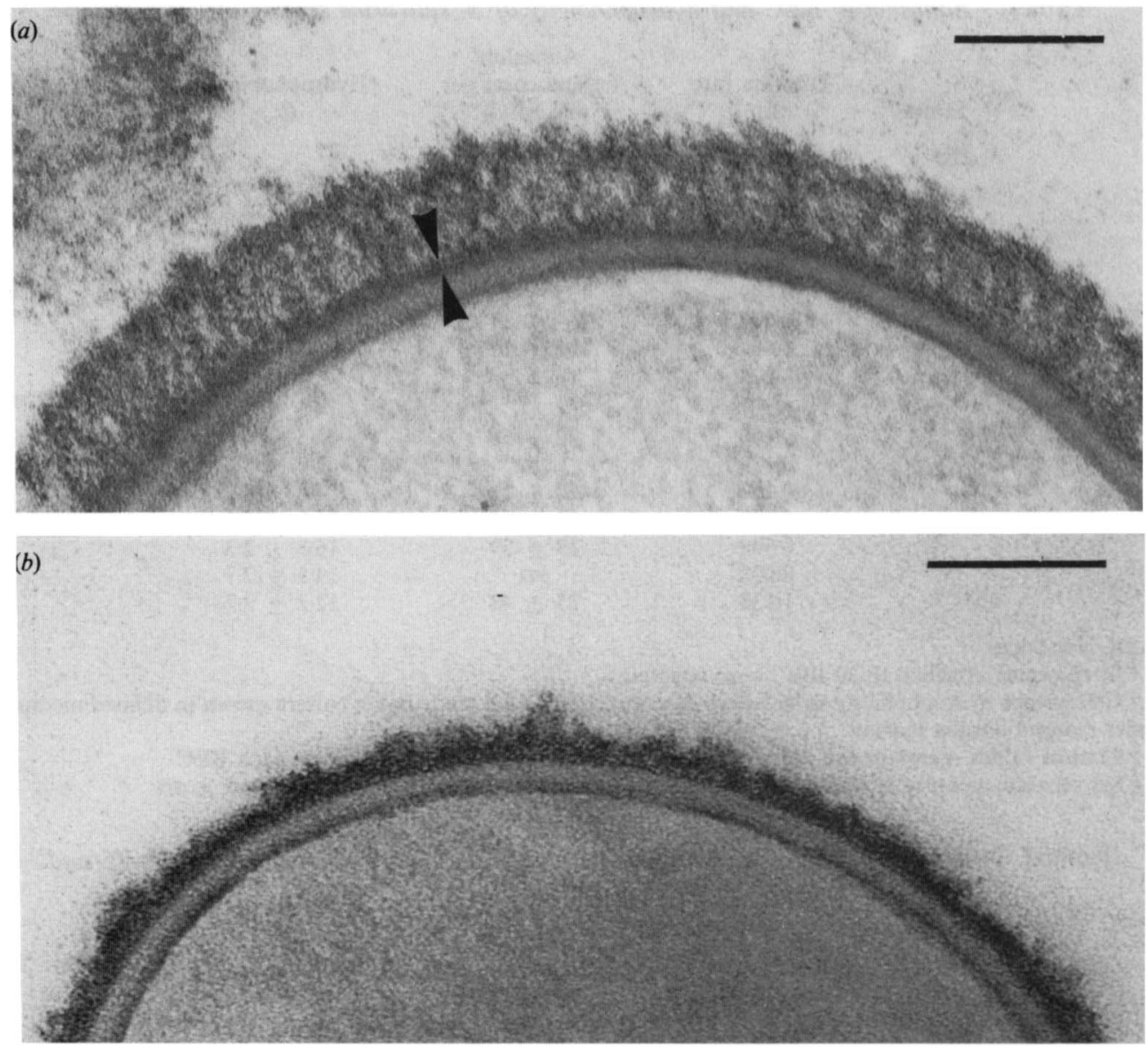

(c)

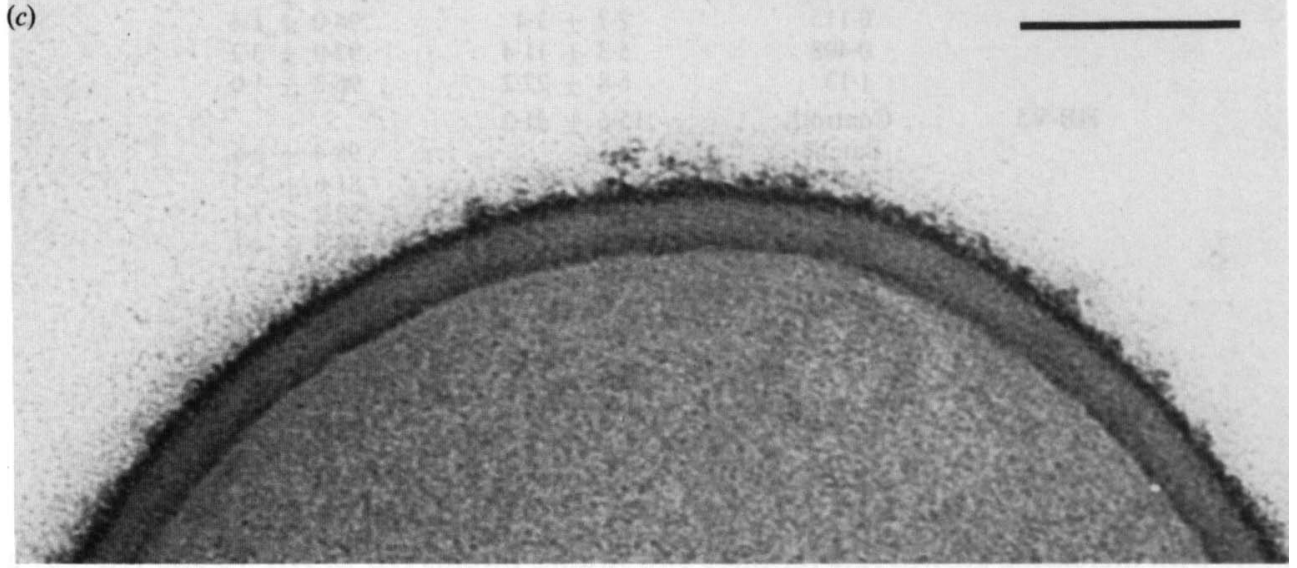

Fig. 1. The sectioned cells in $(a)-(c)$ were all stained with ruthenium red, but were not post-stained. (a) $S$. salivarius strain HB-V5 at a growth rate of $0.15 \mathrm{~h}^{-1}$. The ruthenium red reveals the $73 \mathrm{~nm}$ fibrils responsible for coaggregation with $V$. parvula $\mathrm{V} 1$. No long fibrils are visible in this section. The electron-dense RRL can be seen underneath the fibrils (see arrowheads). (b) Strain HB-B at a growth rate of $1.0 \mathrm{~h}^{-1}$ showing the thick $(19.5 \pm 3.8 \mathrm{~nm})$ dense RRL outside the cell wall. (c) Strain HB-B at a growth rate of $0 \cdot 15 \mathrm{~h}^{-1}$ showing a thin $(12 \cdot 3 \pm 4 \cdot 8 \mathrm{~nm}) \mathrm{RRL}$ outside the cell wall. Bar markers represent $100 \mathrm{~nm}$. 
Table 3. RRL thickness for S. salivarius $H B$ and mutants

\begin{tabular}{|c|c|c|c|}
\hline Strain & $\begin{array}{l}\text { Dilution rate } \\
\qquad\left(\mathrm{h}^{-1}\right)\end{array}$ & $\begin{array}{c}\text { RRL } \\
\text { thickness } \\
(\mathrm{nm})^{*}\end{array}$ & $\begin{array}{c}\text { Significance } \\
\text { value }\end{array}$ \\
\hline HB & $\begin{array}{l}0.221 \\
0.717\end{array}$ & $\begin{array}{l}16 \cdot 12 \pm 2.42 \\
16 \cdot 10 \pm 2.39\end{array}$ & $P=0.98$ \\
\hline $\begin{array}{l}\text { HB-B } \\
\text { (Batch 1) }\end{array}$ & $\begin{array}{l}0 \cdot 106 \\
1 \cdot 138\end{array}$ & $\begin{array}{l}11.86 \pm 3.78 \\
16.34 \pm 4.27\end{array}$ & $P=0.0065$ \\
\hline $\begin{array}{l}\text { HB-B } \\
\text { (Batch 2) }\end{array}$ & $\begin{array}{l}0 \cdot 10 \\
1 \cdot 1\end{array}$ & $\begin{array}{l}12 \cdot 26 \pm 4.82 \\
19 \cdot 45 \pm 3 \cdot 48\end{array}$ & $P<10^{-6}$ \\
\hline HB-7 & $\begin{array}{l}0 \cdot 15 \\
1 \cdot 0\end{array}$ & $\begin{array}{l}12.89 \pm 4.71 \\
15.00 \pm 2.80\end{array}$ & $P=0.039$ \\
\hline HB-V5 & $\begin{array}{l}0 \cdot 15 \\
1 \cdot 0\end{array}$ & $\begin{array}{l}11.97 \pm 3.73 \\
13.89 \pm 2.88\end{array}$ & $P=0.029$ \\
\hline HB-V51 & $\begin{array}{l}0.15 \\
1.0\end{array}$ & $\begin{array}{l}13 \cdot 22 \pm 3 \cdot 61 \\
14 \cdot 14 \pm 2 \cdot 65\end{array}$ & $P=0.268$ \\
\hline
\end{tabular}

rate of $0 \cdot 1 \mathrm{~h}^{-1}$, showing the dense fibrillar layer and the underlying RRL. Fig. $1(b)$ shows the thick RRL of HB-B at high growth rate $\left(1 \cdot 138 \mathrm{~h}^{-1}\right)$; Fig. $1(c)$ shows the thinner RRL of HB-B at low growth rates $\left(0.15 \mathrm{~h}^{-1}\right)$. Measurements were made of the thickness of the RRL from 30 individual cells for each strain at low and high growth rates $\left(0.15\right.$ and $\left.1.0 \mathrm{~h}^{-1}\right)$. Statistical analysis was carried out to examine the data for differences in the thickness of the layers. Table 3 shows the observed mean and standard deviations of the measured RRL for strains HB, HB-7, HB-V5 and HB-V51, and for two separate chemostat batches of HB-B. No significant difference was observed for the RRL thickness between the growth rates for strain $\mathrm{HB}(P=0.98)$ or strain HB-V51 $(P=0 \cdot 268)$. Strains HB-7 and HB-V5 both showed significant differences between the RRL thickness for low and high growth rates $(P=0.039$ and 0.029 respectively). The measurements of the RRL thickness for both batches of strain HB-B showed a significant increase in the thickness with increasing growth rate $\left(P=0.0650\right.$ and $\left.P<10^{-6}\right)$. There was no significant difference in the thicknesses of the RRL of strain HB-B at low growth rates between the batches $(P=0.725)$, but there was a significant increase in the thickness of the RRL of HB-B between the batches at the high growth rates $(P=0.00318)$.

\section{Cell-surface proteins}

Cells from low $\left(0 \cdot 15 \mathrm{~h}^{-1}\right)$ and high $\left(1.0 \mathrm{~h}^{-1}\right)$ growth rates of $S$. salivarius $\mathrm{HB}$ and its mutants were treated with $1 \%(\mathrm{w} / \mathrm{v})$ SLS to extract surface proteins (Jenkinson, 1986). Measurement, by the Lowry technique, of the amount of protein removed from the cell surface consistently showed more protein at the higher growth rate than the lower (data not shown). The extracted proteins, $75 \mu \mathrm{g}$ per lane, were subjected to SDS-PAGE, stained with Coomassie blue and destained. The protein profiles obtained show a complex pattern of bands between molecular masses of $120 \mathrm{kDa}$ down to $14 \mathrm{kDa}$ (Fig. 2). At the highest molecular mass there is a common band for all the strains at all growth rates at approximately $120 \mathrm{kDa}$. Overall, the profiles show a large number of common proteins. A large group between 32.5 and $21.5 \mathrm{kDa}$ occurs with nearly all the strains at both growth rates, although strain HB-V5 (lanes 8 and 9) does show some variation in the strength of the bands in comparison to strains HB, HB-B, HB-7 and HB-V51. The group of bands between 39 and $90 \mathrm{kDa}$ show the most variability with increasing growth rate. A band at $82 \mathrm{kDa}$ shows quite strongly only at the low growth rate $\left(0 \cdot 15 \mathrm{~h}^{-1}\right)$ and is much weaker at the higher growth rates. A band at $70 \mathrm{kDa}$ appears stronger at high growth rates than at the low with the exception of strain HB-V5 where the band is very faint. The 56, 40.5 and 39 $\mathrm{kDa}$ bands also appear stronger at the high growth rate than the lower. The major band of all the strains occurs at a molecular mass of approximately $15.5 \mathrm{kDa}$, although again the bands for HB-V5 and HB-V51 do appear to contain less of this particular protein. Lane 12 shows the effect 


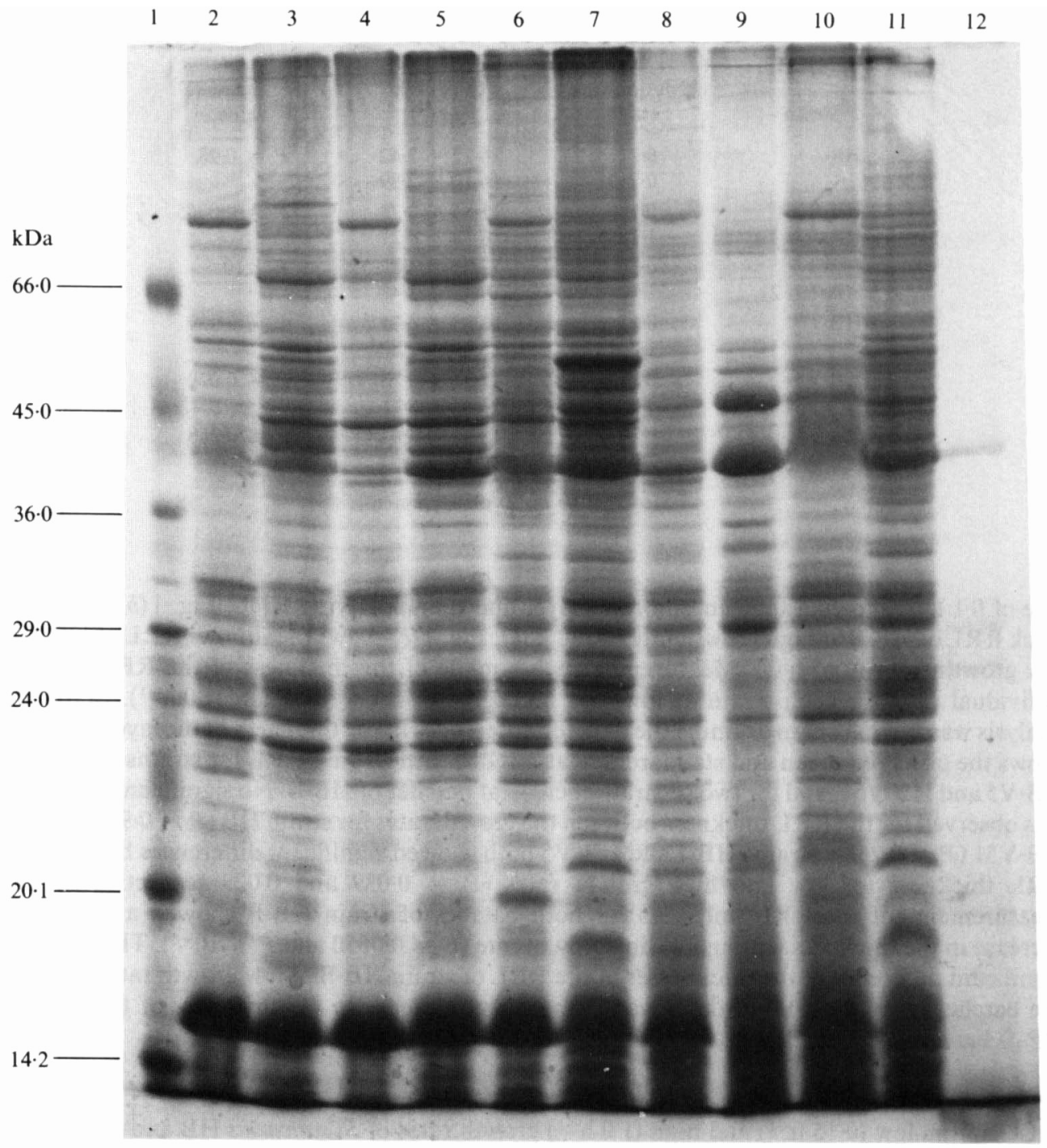

Fig. 2. SDS-PAGE analysis of SLS extracted cell surface proteins of $S$. salivarius $H B$ (lanes 2 and 3 ) and the four mutants, HB-B (lanes 4 and 5), HB-7 (lanes 6 and 7), HB-V5 (lanes 8 and 9) and HB-V51 (lanes 10 and 11$)$. Lanes $2,4,6,8$ and 10 are SDS-PAGE protein profiles from cells at low growth rates $(0 \cdot 1$ $\left.\mathrm{h}^{-1}\right)$ and lanes $3,5,7,9$ and 11 are profiles from cells at high growth rates $\left(1 \cdot 0 \mathrm{~h}^{-1}\right)$. Lane 12 shows the effect of protease treatment $\left(20 \mu \mathrm{g} \mathrm{ml}^{-1}\right)$ on strain HB-B at high growth rate $\left(1.0 \mathrm{~h}^{-1}\right)$ before extraction of proteins with SLS. The molecular mass standards are shown in lane 1.

of incubation of strain HB-B $\left(1.0 \mathrm{~h}^{-1}\right)$ with $20 \mu \mathrm{g}$ protease $\mathrm{ml}^{-1}$ before extraction of the surface proteins: nearly all the major cell surface proteins have been broken down by the action of the protease, the faint bands at $39,30.5$ and $27 \mathrm{kDa}$ as well as two bands at the highest molecular mass being the only remaining protein bands detectable with Coomassie blue staining. Cells of strains HB and HB-B were washed after extraction with SLS and their hydrophobicity measured by partitioning with hexadecane. Cell surface hydrophobicity was only slightly reduced by the treatment with SLS for strain HB at $0.15 \mathrm{~h}^{-1}(94.6 \pm 0.8$ to $92.8 \pm 1.3 \%)$, while at high growth rate $\left(1.0 \mathrm{~h}^{-1}\right)$ there was a slight increase in the cell-surface hydrophobicity $(90.3 \pm 1.7$ to $94.7 \pm$ 
$3 \cdot 2 \%$ ). Strain HB-B showed a larger reduction at low growth rate of $46.5 \pm 4.5$ to $41.9 \pm 2.5 \%$ while the hydrophobicity at high growth rate was virtually identical at $6.0 \pm 2.8$ and $6.2 \pm 3.5 \%$. The strains were negatively stained after SLS treatment and the fibrils on the fibrillar strains were not removed by SLS. The protein bands are therefore likely to be non-fibrillar cell surface proteins from the wall.

\section{DISCUSSION}

The ability of $S$. salivarius $\mathrm{HB}$ to bind to BEC and to coaggregate with $V$.parvula $\mathrm{V} 1$ does not alter with growth rate. Therefore, the properties of adhesion and coaggregation are not subject to phenotypic variation when $S$. salivarius HB is grown in a chemostat under glucose limitation. Since the organism adheres to continually desquamating cells on the tongue, it would be an advantage for indigenous $S$. salivarius cells to be able to adhere maximally under different conditions of substrate availability in order to re-adhere to newly exposed sites on the epithelial cells.

These results differ from those of Weerkamp et al. (1984) who reported that the amounts of $\mathrm{AgB}$ and $\mathrm{AgC}$ on $S$. salivarius $\mathrm{HB}$ varied considerably during growth at different dilution rates and that they varied independently of each other. At higher growth rates $\left(0.64\right.$ and $\left.0.9 \mathrm{~h}^{-1}\right)$ cells grown under glucose limitation produced very low amounts of $\mathrm{AgB}$ and $\mathrm{AgC}$ as detected by rocket immune electrophoresis. In contrast, our results showed high levels of coaggregation and adhesion at all growth rates tested. It is possible that a reduction in the antigen concentration may not be expressed as a reduction in the adhesive capacities of the strains if small amounts of the antigen are still able to carry out the observed function. We have not quantified the relative amounts of $\mathrm{AgB}$ and $\mathrm{AgC}$ in this study to test this hyopothesis.

In the study of Weerkamp \& Handley (1986) it was reported that the number of fibrillar cells in a population varied with the growth rate of $S$. salivarius HB under glucose limitation. However, the cells in this study had been freeze dried and then reconstituted in water before negative staining and electron microscopy, a process which could damage the fibrils and lead to artefacts. We found that SDS-PAGE protein profiles of $S$. salivarius are different before and after freeze drying. Also, autoaggregation and a reduction in the coaggregative ability of the cells occurred after freeze drying (D.W.S. Harty, unpublished observations), supporting the suggestion that freeze drying may damage the cell surface.

This is the first quantified observation showing lack of phenotypic variability of the adhesion processes for an oral streptococcus, as previous reports, particularly on $S$. sanguis have suggested that adhesion varies, depending on growth rate (Rosan et al., 1982; Campbell et al., 1983). S. sanguis, however, adheres to the non-desquamating tooth surface and maintenance of maximal adhesion ability under all conditions of substrate availability may be less important in this ecological niche.

Cell surface hydrophobicity of the $S$. salivarius strains did not vary with growth rate when fibrils were present. This is because fibrils have hydrophobic properties (Weerkamp et al., 1987) and mask the underlying properties of the cell wall. Strain HB-B showed a very high variability in cell surface hydrophobicity, with values being highest at low growth rates and lowest at high growth rates. A similar observation has also been made for strains of $S$. milleri and $S$. mutans grown in a chemostat under glucose limitation (Rogers et al., 1984). The loss of affinity of strain HB-B for hexadecane after growth at high growth rates indicated that the cells had become hydrophilic and that changes in the cell surface had occurred. It is possible that cell surface hydrophobicity is due mainly to the polysaccharides on the cell surface as protease treated cells lost all except three protein bands, but cell surface hydrophobicity was not reduced. Ruthenium red fixation of the hydrophilic HB-B cells grown at high growth rate $\left(1.0 \mathrm{~h}^{-1}\right)$ showed that they had a significantly thicker RRL when compared to the hydrophobic cells grown at low growth rate $\left(0 \cdot 15 \mathrm{~h}^{-1}\right)$. This showed that more polyanionic polymers, probably polysaccharide, had been produced on the cell surface at the high growth rates. At high growth rates more energy is available for the synthesis of cellular material as the proportion of the total energy available required for maintenance energy is less (Harty \& Handley, 1988). The underlying wall thickness 
did not appear to vary although this was not measured in this study. The composition and function of the RRL of $S$. salivarius is unknown although it may contain LTA and the Lancefield group $\mathrm{K}$ antigen (Handley et al., 1988). The presence of a polysaccharide containing RRL is common in streptococci and has been observed on a tufted $S$. sanguis strain (Hesketh et al., 1987), on a fimbriate $S$. sanguis strain (P. S. Handley, unpublished observation) and on $S$. milleri and faecalis strains (P. S. Handley, unpublished observations). The RRL of $S$. salivarius HB does not take part in septum formation as it is excluded from the septum during cell division (Handley et al., 1988) indicating that it may not be part of the cell wall.

Although the thickness of the RRL varies between high and low growth rates for HB-B, HB-7 and HB-V5, but not for HB and HB-V51, there is no apparent reason for this observation. The variability of the RRL thickness of HB-B between high and low growth rates is the greatest for any of the strains, and this may be a function of the loss of the fibrillar layer which may stabilize the RRL, as there is no variation in the thickness of the RRL of strain HB under the dense fibrillar layer. However, strain HB-V51 only carries very sparse short fibrils $(63 \mathrm{~nm})$ (Weerkamp et al., 1986), and the thickness of this RRL does not differ with increasing growth rate. The various mutations giving rise to each mutant may produce these differences in phenotypic variability between RRLs, especially as strain HB-V51 has been chemically mutated twice, first to produce the mutant HB-V5 from strain HB, and again to produce HB-V51 (Weerkamp et al., 1986).

In addition to the increased amounts of polysaccharide at high growth rates, strains also produced increased amounts of proteins as shown by SDS-PAGE of SLS extracts. The dominant feature of the gels was the large number (about 70) of proteins that all strains growing at either low or high growth rates had in common. A major band at $15.5 \mathrm{kDa}$ was observed on all strains with some variation of relative amounts between the strains. A protein of similar molecular mass, $16 \mathrm{kDa}$, was observed on $S$. sanguis strains and was found to be hydrophobic (Jenkinson, 1986). In this study treatment with SLS removed some of the $15.5 \mathrm{kDa}$ protein but did not reduce the cell surface hydrophobicity. A $15 \cdot 5 \mathrm{kDa}$ protein has also been found in extracts of $S$. sanguis FW213 and adhesion deficient mutants (P. S. Handley, unpublished observations), indicating that this may be a common protein in oral streptococci.

At higher growth rates more of the 70, 56, 40.5 and $39 \mathrm{kDa}$ proteins were produced on the cell surface, showing some phenotypic variation of cell surface proteins. As with the polysaccharides more protein is produced when there is increased substrate availability. The functions of the proteins are not known. Protein bands at 43 and $45 \mathrm{kDa}$ have recently been suggested to be involved with adhesion and surface hydrophobicity in $S$. sanguis Challis (Jenkinson \& Carter, 1988). The cell surface proteins from $S$. salivarius in this study were not fibrillar as SLS did not extract the fibrils, indicating that they were extracted from the RRL and/or the cell wall itself.

In conclusion, $S$. salivarius $\mathrm{HB}$ exhibits both phenotypically stable and phenotypically variable cell-surface properties. Cell surface protein and polysaccharide production vary with growth rate, but adhesion to BEC, coaggregation with $V$. parvula $\mathrm{V} 1$ are phenotypically stable, allowing the survival of the organism in an environment which has selected for adhesive organisms.

This work was supported by an MRC project grant to D.W.S.H. (no. 8506176). We are grateful to the Smith Kline Foundation for a grant for electrophoresis equipment.

\section{REFERENCES}

Campbell, L. K., Knox, K. W. \& Wicken, A. J. (1983). Influence of growth conditions on adherence of Streptococcus mutans Ingbritt to saliva-coated hydroxyapatite. Infection and Immunity 39, 445-448.

Carlsson, J. \& Elander, B. (1973). Regulation of dextransucrase formation by Streptococcus sanguis. Caries Research 7, 89-101.

Christie, A. O. \& Porteous, J. W. (1962). The cultivation of a single strain of Actinomyces israelii in simplified chemically defined medium. Journal of General Microbiology 28, 443-454.

Ellwood, D. C. \& HunTER, J. R. (1976). The mouth as a chemostat. In Continuous Culture 6: Applications and New Fields, pp. 270-281. Edited by A. C. R. Dean, D. C. Ellwood, C. G. T. Evans \& J. Melling. Chichester: Ellis Horwood. 
Handley, P. S., Carter, P. L. \& Fielding, J. (1984). Streptococcus salivarius strains carry either fibrils or fimbriae on the cell surface. Journal of Bacteriology 157, 64-72.

Handley, P. S., Harty, D. W. S., Wyatt, J. E., Brown, C. R., Doran, J. P. \& GibBS, A. C. C. (1987). A comparison of the adhesion, coaggregation and cell-surface hydrophobicity properties of fibrillar and fimbriate strains of Streptococcus salivarius. Journal of General Microbiology 133, 3207-3217.

Handley, P. S., Hargreaves, J. \& Harty, D. W. S. (1988). Ruthenium red staining reveals surface fibrils and a layer external to the cell wall in Streptococcus salivarius HB and adhesion deficient mutants. Journal of General Microbiology 134, 31653172.

HaRTy, D. W. S. \& Handley, P. S. (1988). Fermentation products, amino acid utilization, maintenance energies and growth yields for the fibrillar Streptococcus salivarius $\mathrm{HB}$ and a non-fibrillar mutant $\mathrm{HB}-\mathrm{B}$ grown in continuous culture under glucose limitation. Journal of Applied Bacteriology 65, 143-152.

HaRTY, D. W. S. \& Handley, P. S. (1989). The effect of changing growth rate on the expression of surface properties of fibrillar Streptococcus salivarius HB. $X$ th Lancefield International Symposium on Streptococci and Streptococcal Diseases, Köln, FRG. Edited by R. Lutticken. Stuttgart \& New York: Gustav Fischer (in the Press).

Hesketh, L. M., Wyatt, J. E. \& Handley, P. S. (1987). Effect of protease on the cell surface structure, hydrophobicity and adhesion of tufted strains of Streptococcus sanguis biotypes I and II. Microbios 50, 131-145.

JACQues, N. A., HARDY, L., CAMPbell, L. K., KNoX, K. W., Evans, D. \& Wicken, A. J. (1979). Effect of carbohydrate source and growth conditions on the production of lipoteichoic acid by Streptococcus mutans Ingbritt. Infection and Immunity 26, 1079 1087.

JENkinson, H. F. (1986). Cell-surface proteins of Streptococcus sanguis associated with cell hydrophobicity and coaggregation properties. Journal of General Microbiology 132, 1575-1589.

Jenkinson, H. F. \& CARTER, D. A. (1988). Cell surface mutants of Streptococcus sanguis with altered adherence properties. Oral Microbiology and Immunology 3, 53-57.

Knox, K. W., Jacques, N. A., Campbell, L. K., Wicken, A. J., Hurst, S. F. \& Bleiweis, A. S. (1979). Phenotypic stability of the cell wall of Streptococcus mutans Ingbritt grown under various conditions. Infection and Immunity 26, 1071-1078.

KNox, K. W., HaRdy, L. N. \& WiCKen, A. J. (1986). Comparative studies on the protein profiles and hydrophobicity of strains of Streptococcus mutans serotype c. Journal of General Microbiology 132, 2541-2548.
LaEmmi, U. K. \& Favre, M. (1973). Maturation of the head of bacteriophage T4. 1. DNA packaging events. Journal of Molecular Biology 80, 579-599.

LuFT, J. H. (1971). Ruthenium red and violet. 1. Chemistry, purification, methods of use for electron microscopy and mechanism of action. Anatomical Record 171, 347-368.

Rogers, A. H., Pilowsky, K. \& Zilm, P. S. (1984). The effect of growth rate on the adhesion of the oral bacteria Streptococcus mutans and Streptococcus milleri. Archives of Oral Biology 29, 147-150.

Rosan, B., Applebaum, B., Campbell, L. K., KnoX, K. W. \& WICKEN, A. J. (1982). Chemostat studies of the effect of environmental control on Streptococcus sanguis adherence to hydroxyapatite. Infection and Immunity 35, 64-70.

Rosenberg, M., Gutnick, D. \& Rosenberg, E. (1980). Adherence of bacteria to hydrocarbons: a simple method for measuring cell surface hydrophobicity. FEMS Microbiology Letters 9, 29-33.

Terleckyj, B., Willett, N. P. \& Shockman, G. D. (1975). Growth of several cariogenic strains of oral streptotocci in a chemically defined medium. Infection and Immunity 11, 649-655.

WeERKamp, A. H. \& Handley, P. S. (1986). The growth rate regulates the composition and density of the fibrillar coat on the surface of Streptococcus salivarius $\mathrm{K}^{+}$cells. FEMS Microbiology Letters 33, 179-183.

WEERKAMP,, A. H. \& JaCoBs, T. (1982). Cell wall associated protein antigens of Streptococcus salivarius: purification, properties and function in adherence. Infection and Immunity 38, 233-242.

WeERKAMP, A. H. \& MCBRIDE, B. C. (1981). Identification of a Streptotoccus salivarius cell wall component mediating coaggregation with Veillonella alcalescens V1. Infection and Immunity 32, 723-730.

Weerkamp, A. H., van DeR Mei, H. C., Engelen, D. P. E. \& DE WINDT, C. E. A. (1984). Adhesion receptors (adhesins) of oral streptococci. In Bacterial Adhesion and Preventative Dentistry, pp. 85-97. Edited by J. M. ten Cate, F. A. Leach \& J. Arends. Oxford: IRL Press.

Weerkamp, A. H., Handley, P. S., BaARs, A. \& Slot, J. W. (1986). Negative staining and immunoelectron microscopy of adhesion-deficient mutants of Streptococcus salivarius reveal that the adhesive protein antigens are separate classes of cell surface fibril. Journal of Bacteriology 165, 746-755.

WeErKaMp, A. H., van Der Mei, H. C. \& Slot, J. W. (1987). Relationship of cell surface morphology and composition of Streptococcus salivarius $\mathrm{K}^{+}$to adherence and hydrophobicity. Infection and Immunity 55, 438-445. 